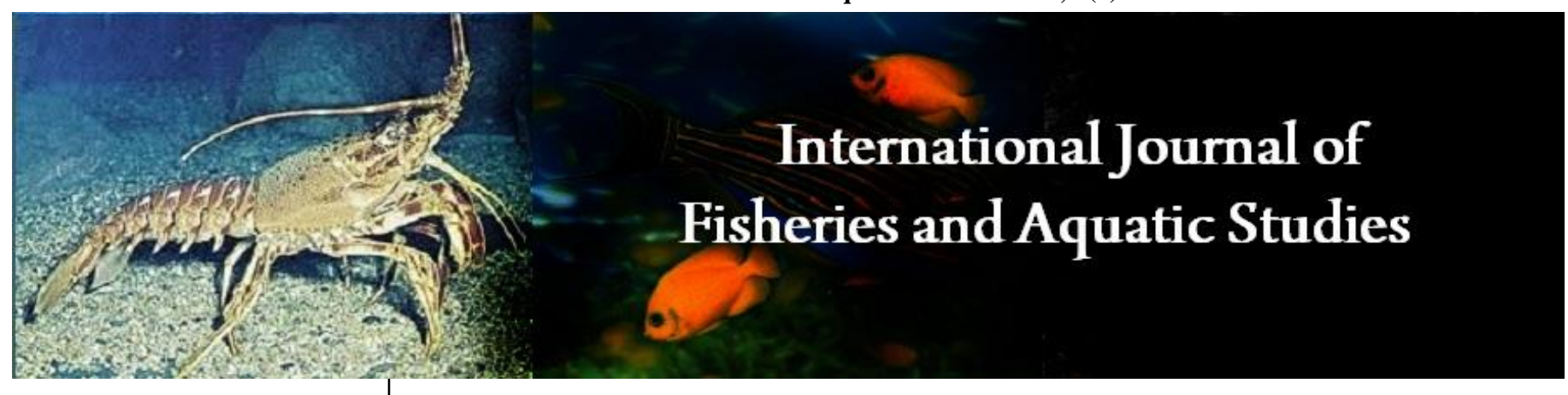

E-ISSN: 2347-5129

P-ISSN: 2394-0506

(ICV-Poland) Impact Value: 5.62

(GIF) Impact Factor: 0.549

IJFAS 2021; 9(5): 30-38

(C) 2021 IJFAS

www.fisheriesjournal.com

Received: 13-07-2021

Accepted: 20-08-2021

Sanjay D Paunikar

Zoological Survey of India,

Northern Regional Centre,

218-Kaulagarh Road, Dehra

Dun, Uttarakhand, India

\section{Species diversity, population structure and conservation status of fishes inhabiting in six different wetlands of Uttar Pradesh}

\section{Sanjay D Paunikar}

DOI: $\underline{\text { https://doi.org/10.22271/fish.2021.v9.i5a.2561 }}$

\title{
Abstract
}

The present study was carried out to investigate the species diversity and population structure of freshwater fishes of six wetlands (also called Bird Sanctuaries) of Uttar Pradesh viz., Patna, Nawabganj, Sandi, Lakh Bahosi, Saman and Sur Sarovar. The sampling was done from three years period 2017 to 2020. The results of present investigation revealed the occurrence of twenty fish species in all the study areas belonging to four orders viz. Cypriniformes, Mastacembeliformes, Perciformes and Siluriformes and 11 families i.e. Cyprinidae, Cobitidae, Nemachilidae, Mastacembelidae, Channidae, Osphronemidae, Heterorpnuestidae, Sisuridae, Bagaridae, Chichlidae and Ambassidae. In all the study wetlands Cyprinidae was found to be dominant (35\%), Osphronemidae (20\%), Mastacembelidae, (10\%), followed by family Cobitidae, Nemacheilidae, Channidae, Sisuridae, Bagaridae, Heterorpnuestidae and Ambassidae showed least contribution of 5\% each. The fish diversity indices i.e. Shannon weiner $(\mathrm{H})$ and Evenness (e) at all the six wetlands were $1.31,0.9084 \& 0.5710,1.2068 \& 0.6202,1.0961 \& 0.6117$, $1.1552 \& 0.4649,0.9080 \& 0.5068,1.3002 \& 0.6682$ at wetlands viz, Patna, Nawabganj, Sandi, Lakh Bahosi, Saman and Sur Sarovar respectively.

Most of the species recorded in the present study were under 19 Least Concern (95\%) and 1 species namely Chagunius chagunio were found to be under Near Threatened Category (5\%) of the International Union for Conservation of Nature (IUCN).

Keywords: Fish diversity, population structure, conservation status, wetlands, Uttar Pradesh

\section{Introduction}

India is one of the mega biodiversity countries in the world and occupies the ninth position in terms of freshwater mega biodiversity Freshwater biodiversity provides a broad spectrum of invaluable ecosystem services, besides a wide range of goods and services for human societies. The freshwater ecosystems of India include all types of inland wetlands: lakes, rivers, ponds, streams, groundwater, springs, cave waters, floodplains, as well as bogs, marshes and swamps, including 26 Ramsar Sites. India with $2.4 \%$ of global landmass has $4 \%$ of the world's freshwater resources ${ }^{[1,2,3]}$. Studies on fish taxonomy, diversity, population dynamics etc. have been of immense interest to researchers of all times ${ }^{[4,5,6,7]}$. Fishes are one of the most important vertebrate of food chain and provided rich proteins for humans, other several animals and important elements in the economy of many countries of the world $[8,9,10,11,12]$. Fish diversity of lakes, ponds and rivers are essentially represents the fish faunal diversity and their abundance. Lakes, wetlands, ponds and rivers conserved a rich variety of fish species which supports the commercial fisheries ${ }^{[13]}$. The country is rich diversity of such important groups of animals $[14,15,16,17]$.

Indian freshwater fish diversity is very rich with as many as 1,029 species comprising primary, secondary and alien freshwater fishes. Among the primary freshwater fish includes 858 species belonging to 167 genera under 40 families and 12 orders. Further, 137 species of secondary freshwater fishes that frequently enter and thrive in freshwater reaches of rivers are also known from India. 32 species of alien fishes belonging to 21 genera of 9 families and 7 orders are found in freshwater system of India. Out of 16 species are well known potential invasive alien fishes in India ${ }^{[17,18]}$.

India has a wealth of wetland ecosystems that support diverse and unique habitats.

Corresponding Author: Sanjay D Paunikar Zoological Survey of India, Northern Regional Centre, 218-Kaulagarh Road, Dehra Dun, Uttarakhand, India 
Wetlands are important components of watersheds and provide many valuable functions to environment and to society. According to Ramsar Convention, wetlands are world's most productive environment with stunning biological diversity. Wetlands are often described as "Kidneys of land scope" [19]. Around 4- 6\% of earth surface is covered by wetlands. These wetlands provide numerous ecological goods and services but are under tremendous stress due to rapid urbanization, industrialization and agricultural intensification, manifested by the shrinkage in their areal extent, and decline in the hydrological, economic and ecological functions they perform. The wetland wealth of India in terms of their geographic distribution and extent, ecosystem benefits they provide, and the various stresses they are exposed ${ }^{[20]}$.

The state Uttar Pradesh located between $23^{0} 52^{\prime}-31^{0} 28^{\prime} \mathrm{N}$ latitude and $77^{\circ} 04^{\prime}-84^{0} 38^{\prime} \mathrm{E}$ longitude is the most populated and one of the largest states of India blessed with vivid aquatic resources. The state contributes about $14.11 \%$ of the national fish biodiversity and fishery resources in the state are available in plenty in the form of rivers and their tributaries, reservoirs, wetlands, lakes, ponds and tanks that exhibit rich genetic and fish diversity and offer considerable scope for inland fisheries development and aquaculture ${ }^{[21,22]}$.

Uttar Pradesh has vast potential of fish faunal diversity. Several workers studied the fish fauna of Uttar Pradesh [23, 24] and more recently by Gopi and Kosygin Bano and Serajuddin $[25,26]$.The current assessment of the rivers of Uttar Pradesh reveals about a total biodiversity 124 species 74 genera and 28 families. This diversity has contributed of about $14.11 \%$ of the India's freshwater fish diversity. Over all, the diversity among families was recorded to be widely distributed and common to all rivers ${ }^{[22]}$.

Uttar Pradesh has network of wetlands, ponds, lakes, reservoirs and rivers. In U.P. State 12 notified Wetlands also called Bird Sanctuaries, namely-Nawabganj Bird Sanctuary (Unnao District), Sur Sarovar Bird Sanctuary (Agra District), Patna Bird Sanctuary (Etah), Saman Bird Sanctuary
(Mainpuri), Parvati Aranga Bird Sanctuary (Gonda), Bakhira Bird Sanctuary (Sant Kabir Nagar District), Sandi Bird Sanctuary (Hardoi District), Lakh Bahosi Bird Sanctuary (Kannuj District), Surha Tal Bird Sanctuary m (Ballia District), Samaspur Bird Sanctuary (Raibareilly) of which Six sanctuaries viz., Patna Bird Sanctuary Nawabganj Bird Sanctuary, Unnao district, Sandi Bird Sanctuary, Hardoi district, Lakh Bahosi Bird Sanctuary, Kannuj District and Sandi Bird Sanctuary, Hardoi district and Sur Sarovar Bird Sanctuary, Agra district ${ }^{[27]}$.

Some workers investigated fish diversity, composition structures, population dynamics, and conservation status of major and important rivers, like Ganga, Gomati, Yamuna and their tributaries $[28,29,30,31,32]$. Some workers also studied the fishes of different wetlands, ponds and lakes of Uttar Pradesh $[33,34,35,36]$. All these wetlands are a hotspot for large number of living organisms including fish, birds, aquatic plants and animals and these wetlands attracted several bird species and heaven for variety of bird species, but not much known of about other fauna species including fishes of six wetland of Uttar Pradesh. Some fragmentary work has been done on fish diversity of wetlands ecosystem of Uttar Pradesh by Bano and Serajuddin and Prakash and Singh ${ }^{[37,38]}$.

Therefore, the present paper attempted to explore the species diversity, distribution and population structures of six different wetlands, namely, Patna, Nawabganj, Sandi, Lakh Bahosi, Saman and Sur Sarovar of Uttar Pradesh. The different team of Zoological Survey of India, Northern Regional Centre, and Dehradun were surveyed for the inventorisation of different fauna including fishes for the three years, 2017 to 2020 .

\section{Materials and methods}

2.1 Site

To study the Ichthyofaunal diversity of the six wetlands of Uttar Pradesh viz, Patna, Nawabganj, Sandi, Lakh Bahosi Saman, and Sur Sarovar fish samples collected and details given in Table 1.

Table 1: Details of surveyed localities

\begin{tabular}{|c|c|c|c|c|c|c|}
\hline no & Locality & District & Habitat & Latitude & Longitude & Altitude \\
\hline 1 & Patna wetland (Bird sanctuary) & Etah & Lake and surrounding area & $27^{\circ} 31^{\prime} 43.47^{\prime \prime} \mathrm{N}$ & $78^{\circ} 18^{\prime} 54.57^{\prime \prime} \mathrm{E}$ & $173 \mathrm{~m}$ \\
\hline 2 & Nawabganj wetland (Bird Sanctuary) & Unnao & Small swallow lake surrou & & & $123 \mathrm{~m}$ \\
\hline 3 & Sandi wetland (Bird Sanctuary) & Hardoi & Deep water Lake and nearby scrub forest & $27^{\circ} 18072 \mathrm{~N}$ & $079^{\circ} 58049 \mathrm{E}$ & $397 \mathrm{~m}$ \\
\hline 4 & Lakh Bahosi wetland (Bird Sanctuary) & Kannuj & Small swallow lake surrounded by forest patches & $26^{\circ} 36^{\prime \prime} 931 \mathrm{~N}$ & $080^{\circ} 38^{\prime \prime} 931 \mathrm{E}$ & $145 \mathrm{~m}$ \\
\hline 5 & Saman wetland (Bird Sanctuary) & Mainpuri & Swamp, oxbow lake & $27^{\circ} 01^{\prime} 21.91^{\prime \prime} \mathrm{N}$ & $79^{\circ} 11^{\prime} 18.67^{\prime \prime} \mathrm{E}$ & $151 \mathrm{~m}$ \\
\hline 6 & Sur Sarover wetland (Bird Sanctuary) & Agra & Deep water Lake and nearby scrub forest & $27^{\circ} 15^{\prime} 08.23^{\prime \prime} \mathrm{N}$ & $77^{\circ} 50^{\prime} 33.80^{\prime \prime} \mathrm{E}$ & $167 \mathrm{~m}$ \\
\hline
\end{tabular}

\subsection{Collection and identification}

During present study fishes were collected from 2017 to 2020 by using different types of nets i.e. cast net, drag net, hand/ dip net. The collected fish samples were preserved in $10 \%$ formalin and brought in Ichthyology Laboratory of Zoological Survey of India, Northern Regional Centre, Dehradun, and Uttarakhand for further detailed examination.

The threat status of each fish species was assessed according to the different categories as adopted and developed by International Union for Conservation of Nature and Natural Resources (IUCN).

The collected specimens were sorted at species level and all the species obtained were counted. The species identification and confirmation were carried out using available literature ${ }^{5,}$
$7,8,10]$. The different fish species were examined, diagnostic characters and distribution have been provided for each species and given the registration number and deposited in National Zoological Collection (NZC) of Northern Regional Centre, Zoological Survey of India, Dehra Dun, Uttarakhand.

\subsection{Population structure studies}

Information on fish population structure in six different wetlands of Uttar Pradesh was estimated by adopting different diversity indices namely; Shannon and Weiner diversity index (1963), Simpson's evenness index (1949), Margalef species richness index $(1958)^{[39,40,41]}$, and Evenness Index. The total 2306 examples of fishes collected from six different wetlands of Uttar Pradesh. 
Table 2: Showing Species diversity of fishes in six wetlands of Uttar Pradesh

\begin{tabular}{|c|c|c|c|c|}
\hline Sr. No. & Order & Families & \begin{tabular}{|c|} 
Species \\
\end{tabular} & IUCN Status \\
\hline 1 & \multirow{9}{*}{ Cypriniformes } & \multirow{7}{*}{ Cyprinidae } & Amhlypharyngopodon mola (Ham Buch) & $\mathrm{LC}$ \\
\hline 2 & & & Puntius sophore Hamilton & $\mathrm{LC}$ \\
\hline 3 & & & Pethia conchonius (Ham Buch) & $\mathrm{LC}$ \\
\hline 4 & & & Pethia ticto (Ham Buch) & $\mathrm{LC}$ \\
\hline 5 & & & Esomus danricus Hamilton & $\mathrm{LC}$ \\
\hline 6 & & & Chagunius chagunio (Ham Buch) & EN \\
\hline 7 & & & Barilius barna (Ham Buch) & NT \\
\hline 8 & & Nemacheilidae & Nemacheilus botia (Ham Buch) & $\mathrm{LC}$ \\
\hline 9 & & Cobitidae & Lepidocephalichthys guntea (Ham Buch) & $\mathrm{LC}$ \\
\hline 10 & \multirow{3}{*}{ Siluriformes } & Siluridae & Mystus vittatus Bloch & $\mathrm{LC}$ \\
\hline 11 & & Bagaridae & Bagarius bagarius (Ham Buch) & $\mathrm{LC}$ \\
\hline 12 & & Heteropneustidae & Heteropneustes fossilis (Bloch) & $\mathrm{LC}$ \\
\hline 13 & \multirow{6}{*}{ Perciformes } & Channidae & Channa punctata (Bloch) & $\mathrm{LC}$ \\
\hline 14 & & \multirow{3}{*}{ Osphronemidae } & Trichogaster fasciata (Bloch \& Sch.) & $\mathrm{LC}$ \\
\hline 15 & & & Trichogaster lalius (Ham Buch) & $\mathrm{LC}$ \\
\hline 16 & & & Pseudosphromenus cupanus Cuvier & $\mathrm{LC}$ \\
\hline 17 & & Cichilidae & Oreochromis mossambicus Peters & \\
\hline 18 & & Ambassidae & Chanda nama (Ham Buch) & $\mathrm{LC}$ \\
\hline 19 & Mastacembeleformes & \multirow{2}{*}{ Mastacembelidae } & Macrognathus armatus (Ham Buch) & $\mathrm{LC}$ \\
\hline 20 & & & Macrognathus panacalus (Ham Buch) & LC \\
\hline
\end{tabular}

Table 3: Showing fish abundance and percentage at Patna wetland

\begin{tabular}{|c|c|c|c|c|}
\hline Sr. No. & Species & Family & Total Abundance & $\%$ \\
\hline 1 & Puntius sophore Hamilton & Cyprinidae & 11 & 2.82 \\
\hline 2 & Esomus danricus Hamilton & Cyprinidae & 27 & 6.92 \\
\hline 3 & Nemacheilus botia (Ham Buch) & Nemacheilidae & 2 & 0.51 \\
\hline 4 & Lepidocephalichthys guntea (Ham Buch) & Cobitidae & 1 & 0.25 \\
\hline 5 & Channa punctata (Bloch) & Channidae & 60 & 15.38 \\
\hline 6 & Macrognathus panacalus (Ham Buch) & Mastacembelidae & 1 & 0.25 \\
\hline 7 & Trichogaster fasciata (Bloch \& Sch.) & Osphronemidae & 241 & 61.79 \\
\hline 8 & Mystus vittatus Bloch & Sisoridae & 15 & 3.84 \\
\hline 9 & Bagarius bagarius (Ham Buch) & Bagaridae & 20 & 5.12 \\
\hline 10 & Heteropneustes fossilis (Bloch) & Heteropneustidae & 12 & 0.07 \\
\hline
\end{tabular}

Table 4: Showing fish abundance and percentage at Nawabganj wetland

\begin{tabular}{|c|c|c|c|c|}
\hline Sr. No. & Fish Species & Family & Total Abundance & \% \\
\hline 1 & Puntius sophore (Ham Buch) & Cyprinidae & 29 & 5.16 \\
\hline 2 & Pethia conchonius (Ham Buch) & Cyprinidae & 16 & 0.29 \\
\hline 3 & Pethia ticto (Ham Buch) & Cyprinidae & 3 & 0.53 \\
\hline 4 & Esomus danricus (Ham Buch) & Cyprinidae & 157 & 27.98 \\
\hline 5 & Channa punctata (Bloch) & Channidae & 43 & 7.66 \\
\hline 6 & Trichogaster fasciata (Bloch $\&$ Sch.) & Osphronemidae & 308 & 17.27 \\
\hline 7 & Trichogaster lalius (Ham Buch) & Osphronemidae & 5 & 0.84 \\
\hline
\end{tabular}

Table 5: Showing fish abundance and percentage at Sandi wetland

\begin{tabular}{|c|c|c|c|c|}
\hline Sr. No. & Fish Species & Family & Total Abundance & \% \\
\hline 1 & Puntius sophore (Ham Buch) & Cyprinidae & 29 & 7.47 \\
\hline 2 & Esomus danricus Hamilton & Cyprinidae & 58 & 14.94 \\
\hline 3 & Channa punctata (Bloch) & Channidae & 28 & 7.21 \\
\hline 4 & Trichogaster fasciata (Bloch \& Sch.) & Osphronemidae & 255 & 65.72 \\
\hline 5 & Trichogaster lalius (Ham Buch) & Osphronemidae & 17 & 4.38 \\
\hline 6 & Pseudosphromenus cupanus Cuvier & Osphronemidae & 1 & 0.25 \\
\hline
\end{tabular}

Table 6: Showing fish abundance and percentage at Lakh Bahosi wetland

\begin{tabular}{|c|c|c|c|c|}
\hline Sr. No. & Fish Species & Family & Total Abundance & $\%$ \\
\hline 1 & Puntius sophore (Ham Buch) & Cyprinidae & 43 & 7.93 \\
\hline 2 & Esomus danricus Ham Buch) & Cyprinidae & 56 & 10.33 \\
\hline 3 & Amhlypharyngopodon mola (Ham Buch) & Cyprinidae & 5 & 0.92 \\
\hline 4 & Chagunius chagunio (Ham Buch) & Cyprinidae & 2 & 0.36 \\
\hline 5 & Lepidocephalichthys guntea (Ham Buch) & Cobitidae & 1 & 0.18 \\
\hline 6 & Channa punctata (Bloch) & Channidae & 13 & 2.39 \\
\hline 7 & Trichogaster fasciata (Bloch \& Sch.) & Osphronemidae & 373 & 68.81 \\
\hline 8 & Trichogaster lalius (Ham Buch) & Osphronemidae & 35 & 6.45 \\
\hline
\end{tabular}




\begin{tabular}{|c|c|c|c|c|}
\hline 9 & Mastacembelus armatus (Lacepede) & Mastacembelidae & 1 & 0.18 \\
\hline 10 & Macrognathus panacalus (Hamilton) & Mastacembelidae & 2 & 0.36 \\
\hline 11 & Mystus vittatus (Bloch) & Sisoridae & 9 & 1.66 \\
\hline 12 & Heteropneustes fossilis (Bloch) & Heteropneustidae & 2 & 0.36 \\
\hline
\end{tabular}

Table 7: Showing fish abundance and percentage at Saman wetland

\begin{tabular}{|c|c|c|c|c|}
\hline Sr. No. & Fish Species & Family & Total Abundance & \% \\
\hline 1 & Puntius sophore (Ham Buch) & Cyprinidae & 10 & 2.87 \\
\hline 2 & Esomus danricus Ham Buch) & Cyprinidae & 2 & 0.57 \\
\hline 3 & Channa punctata (Bloch) & Channidae & 46 & 13.21 \\
\hline 4 & Trichogaster fasciata (Bloch \& Sch.) & Osphronemidae & 255 & 73.27 \\
\hline 5 & Mystus vittatus (Bloch) & Sisoridae & 28 & 8.04 \\
\hline 6 & Heteropneustes fossilis (Bloch) & Heteropneustidae & 7 & 2.01 \\
\hline
\end{tabular}

Table 8: Showing fish abundance and percentage at Sur Sarovar wetland

\begin{tabular}{|c|c|c|c|c|}
\hline Sr. No. & Fish Species & Family & Total Abundance & \% \\
\hline 1 & Barilius barna (Ham Buch) & Cyprinidae & 1 & 1.14 \\
\hline 2 & Esomus danricus (Ham Buch) & Cyprinidae & 29 & 33.33 \\
\hline 3 & Chagunius chagunio (Ham Buch) & Cyprinidae & 1 & 1.14 \\
\hline 4 & Chanda nama (Ham Buch) & Ambassidae & 18 & 20.68 \\
\hline 5 & Trichogaster fasciata (Bloch \& Sch.) & Osphronemidae & 26 & 29.88 \\
\hline 6 & Heteropneustes fossilis (Bloch) & Heteropneustidae & 1 & 1.14 \\
\hline 7 & Oreochromis mossambicus Peters & Cichilidae & 1 & 1.14 \\
\hline
\end{tabular}

Table 9: Showing Fish Richness, Abundance and diversity indices of six wetland of Uttar Pradesh

\begin{tabular}{|c|c|c|c|c|c|c|}
\hline $\begin{array}{c}\text { Sr. } \\
\text { No }\end{array}$ & $\begin{array}{c}\text { Bird } \\
\text { Sanctuaries }\end{array}$ & $\begin{array}{c}\text { Abundance } \\
(\mathbf{N})\end{array}$ & $\begin{array}{c}\text { Shannon-Weiner } \\
\text { Index (H) }\end{array}$ & $\begin{array}{c}\text { Simpsons Index of } \\
\text { Dominance (D) }\end{array}$ & $\begin{array}{c}\text { Margalefs Richness } \\
\text { Index d=S1/logN }\end{array}$ & $\begin{array}{c}\text { Evenness Index } \\
\mathbf{E}=\mathbf{H} / \mathbf{l o g}(\mathbf{S})\end{array}$ \\
\hline 1 & Patna & 390 & 1.314 & 0.5853 & 1.5085 & 0.5710 \\
\hline 2 & Nawabganj & 561 & 1.2068 & 0.6119 & 0.9479 & 0.6202 \\
\hline 3 & Sandi & 388 & 1.0961 & 0.5344 & 0.8388 & 0.6117 \\
\hline 4 & Lakh Bahosi & 542 & 1.1552 & 0.5052 & 1.7473 & 0.4649 \\
\hline 5 & Saman & 348 & 0.9080 & 0.4391 & 0.8544 & 0.5068 \\
\hline 6 & Sur Sarovar & 77 & 1.3002 & 0.6979 & 1.3813 & 0.6682 \\
\hline
\end{tabular}

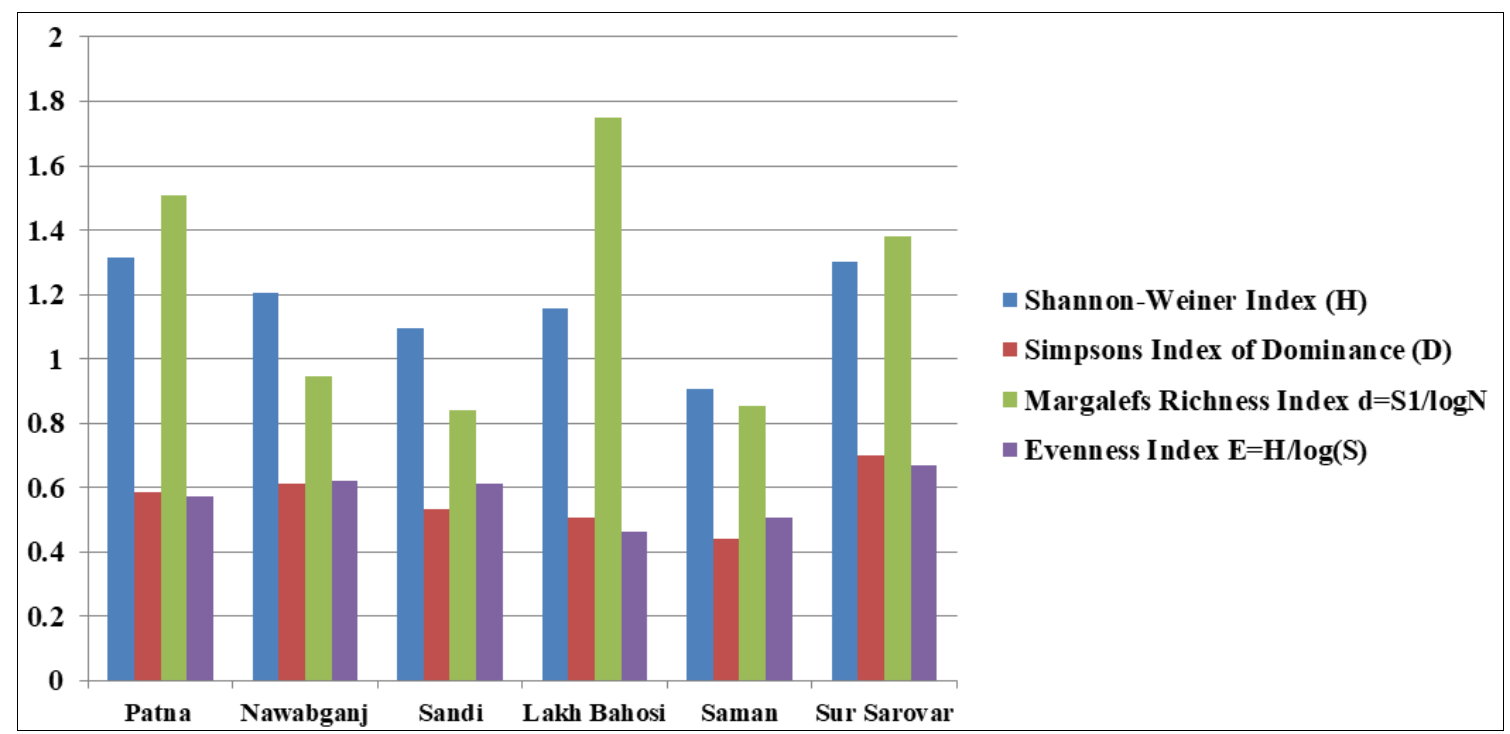

Fig 7: Graph showing various diversity factors in six different wetlands 


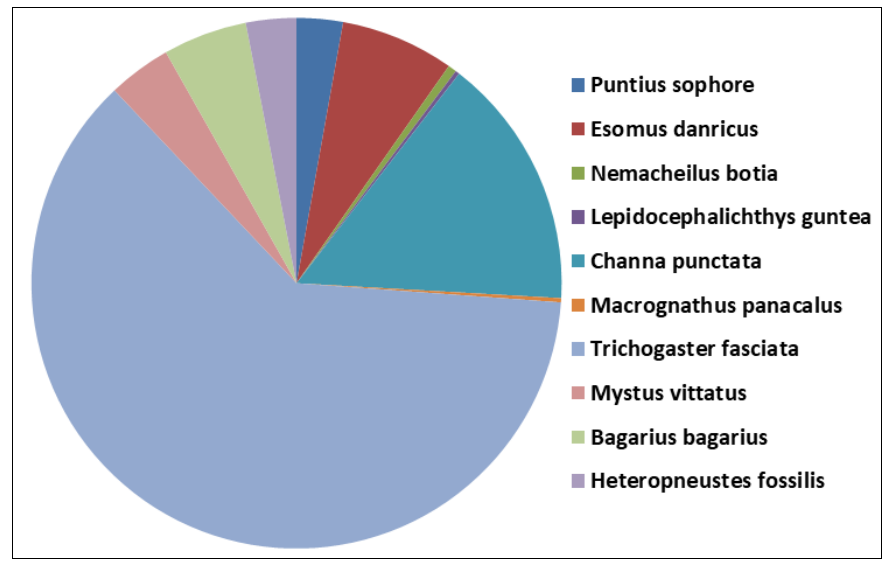

Fig 1: Patna wetland

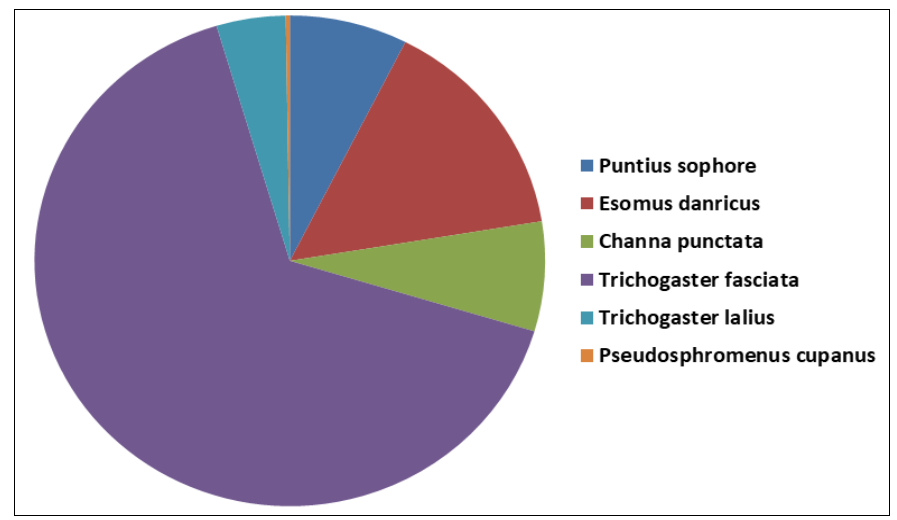

Fig 3: Sandi wetland

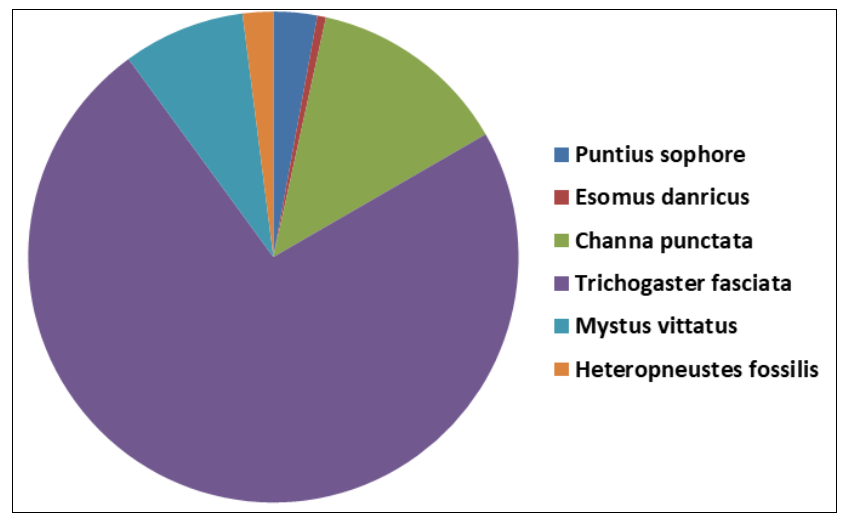

Fig 5: Saman wetland

\section{Results and Discussion}

During the present investigation, for a period of three years (October 2017 to February 2020) a total of 20 fish species belonging to four orders viz., Cypriniformes, Mastacembeliformes, Perciformes and Siluriformes and 11 families i.e. Cyprinidae, Cobitidae, Nemachilidae, Mastacembelidae, Channidae, Osphronemidae, Heterorpnuestidae, Sisuridae, Bagaridae, Chichlidae and Ambassidae. In all the studies Bird Sanctuaries, Cyprinidae was found to be dominant, Mastacembelidae, Osphronemidae followed by family Cobitidae, Nemacheilidae, Channidae, Sisuridae, Bagaridae, Heterorpnuestidae and Ambassidae showed least contribution including variety of fishes were present endangered, ornamental, aquarium, migratory, food and exotic/ Invasive alien species of fishes etc. In all the study area Cyprinidae was found to be dominant $(35 \%)$, Osphronemidae (20\%), Mastacembelidae (10\%), followed by family Cobitidae, Nemacheilidae, Channidae, Sisuridae,

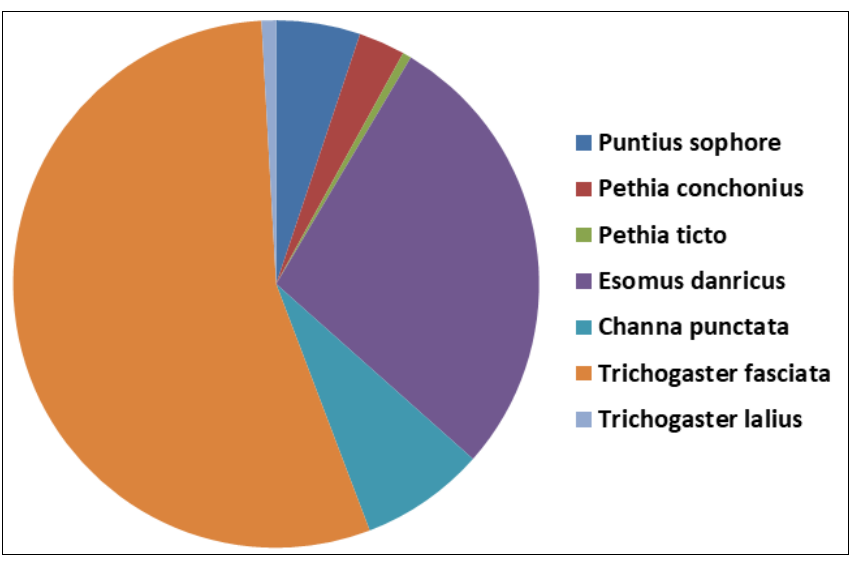

Fig 2: Nawabganj wetland

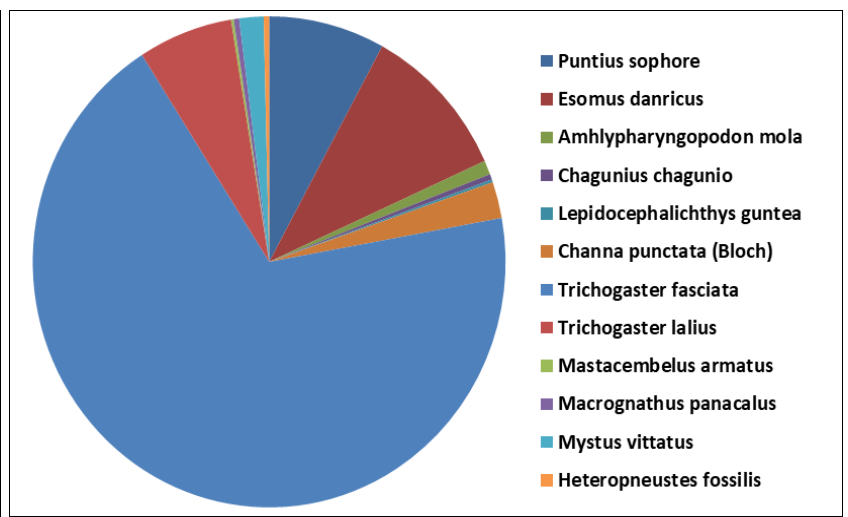

Fig 4: Lakh Bahosi wetland

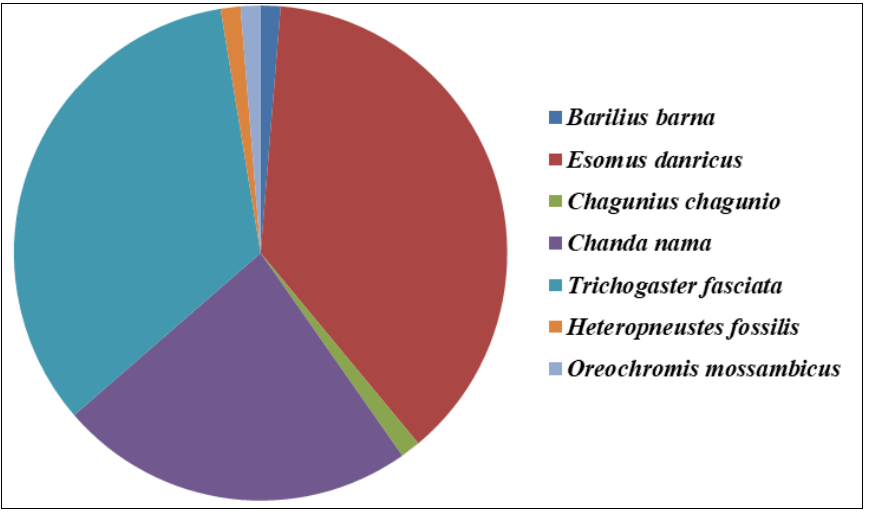

Fig 6: Sur Sarovar wetland

Bagaridae, Heterorpnuestidae and Ambassidae showed least contribution of $5 \%$ each representing single species. Threat status of the fishes studied in six different wetlands indicated that most of the species (19) are under Least Concern (LC) and one species viz., Chagunius chagunio under Near Threatened category (Table 2).

The dominance of Cyprinids in the populations structure, as seen during the present study, was due to their high adaptive variability to occupy all possible habitats and presence of appropriate environment, bottom, depth, water current and food abundance etc for cyprinids which is in accordance with the observed by Dass and Nath, Marais Kar et al. Mishra Gandotra and Poonam; Razak et al.; Shukla Das [42,43,44,45,46,47, ${ }^{48}$ ] (Table 3-8 \& Fig 1-6).

Wetlands wise data of fish abundance revealed that at Patna wetland 10 fish species were collected $(\mathrm{H}=1.314)$ i.e. Puntius sophore, Esomus danricus, Nemacheilus botia, Lepidocephalicthys guntea, Channa punctata, Macrognathus 
panacalus Trichogaster fasciata, Mystus vittatus, Bagarius bagarius, Heteropneustes fossilis etc. At Nawabganj wetland 7 species were recorded $(\mathrm{H}=1.206)$ i.e. Puntius sophore, Pethia conchonis, Pethia ticto, Esomus danricus, Channa punctata, Trichogaster fasciata and Trichogaster lalius. At Sandi wetland 6 species were recorded $(\mathrm{H}=1.096)$ i.e. Puntius sophore, Esomus danricus, Channa punctata, Trichogaster fasciata, Trichogaster lalius and Pseudosphromenus cupanus. At Lakh Bahosi wetland 12 species were recorded $(\mathrm{H}=1.1552)$ i.e. Puntius sophore, Esomus danricus, Amhlypharyngopodon mola, Chagunius chagunio, Lepidocephalichthys guntea, Channa punctata, Trichogaster fasciata, Trichogaster lalius, Mastacembelus armatus, Macrognathus panacalus, Mystus vittatus and Heteropneustes fossilis. At Saman wetland 6 species were recorded $(\mathrm{H}=0.098)$ i.e. Puntius sophore, Esomus danricus, Channa punctata, Trichogaster fasciata, Mystus vittatus and Heteropneustes fossilis. At Sur Sarovar wetland 7 species were recorded $(\mathrm{H}=1.300)$ i.e. Barilius barna Esomus danricus, Chagunius chagunio, Chanda nama, Trichogaster fasciata, Heteropneustes fossilis and Oreochromis mossambicus (Table 9, Fig.7).

Moreover, a comparative study of various wetlands revealed that there was more species found in the Lakh Bahosi (12) wetland followed by Patna, Nawabganj, Sur Sarovar, Sandi and Saman wetlands. There was more abundance fishes found in Nawabganj (561) as compare to other wetlands. In Lakh Bahosi fishes found (542) followed by Patna (390), Sandi (388), Saman (348) and lowest found in Sur Sarovar (77) wetlands. Among the species abundance, Trichogaster fasciata species found in wetlands as compare to other species. The cyprinds, Esomus danricus and Channa punctatus species found in all the wetlands. The other cyprind Puntius sophore found in six wetlands and other species found in four, three, two and one wetlands respectively.

Husaain ${ }^{[49]}$ reported The 40 species of fishes from Asan wetland, Dehradun. Of the forty species, Barilius bendelis is was found to be distributed in all the locations. Das et al. ${ }^{[50]}$ studied the faunal diversity of RBWC, Cooch Behar. They reported the occurrence of 53 species of fishes belonging to nine orders, 22 families and 11 sub families in different beels of Rasik Beel wetland complex. Kumar et al. ${ }^{[19]}$ recorded only 11 species under 5 families from Sandi wetland of Uttar Pradesh. At present study only 6 species were observed from Sandi wetland. Suvi and Shubi [51] studied icthyofauna of wetland ecosystem represented by 21 Species belongs to 7 orders and 13 families and 15 genera from Kerala. The family Cyprinidae showed maximum individual diversity followed by the order Perciformes with 5 families, each orders Siluriforms, Beloniforms, and Mugiliforms. Scorpaeniformes and Tetraodoniiformes with 1 family noted during the study period. They also found the family Cyprinidae showed maximum individual diversity.

Later, Bano and Seraiuddin ${ }^{[37}$ recorded 31 species belonging to 23 genera, 9 orders and 16 families were recorded from Bakhira Tal, Uttar Pradesh. Gautam et al. ${ }^{[52]}$ reported 24 species of fishes from Rihand reservoir, Uttar Pradesh. Recently, Prakash ${ }^{[53]}$ identified 29 species of fishes belonging to 20 genera, 15 families and 8 orders during entire survey and observation from Semara Taal, A Wetland of District Siddharthnagar Uttar Pradesh. This was the first systematic survey on the fish diversity of this wetland. Order Siluriformes was found most dominant represented by 10 species, followed by Cypriniformes with 7 species;
Perciformes and Ophiocephaliformes are with 3 species; Osteoglossiformes, and Synbranchiformes with 2 species while Clupeiformes and Beloniformes representing by only one species. Prakash and Singh ${ }^{[38]}$ reported 35 species of fishes belonging to 23 genera, 17 families and 8 orders from Baghel Taal, a Wetland of District Bahraich, Uttar Pradesh. They further listed species per latest version of IUCN Red List, out of 35 species of fishes identified, 2 species comes under EN (endangered), 4 species come under NT (near threatened), 23 under LC (least concern) and 6 species are NE (not evaluated) so far. Cypriniformes was found to be the most dominant group as compared to other orders in six wetlands. The present finding is similar to that of the studies carried out by Shinde et al. ${ }^{[1]}$ and Jaiswal and Ahirrao ${ }^{[54]}$. Out of 11 families, Cyprinidae was most dominant with 8 species recorded during the current study. Devi Prasad et al. [55] reported 45 species from wetlands of Mysore where Cyprinidae was dominant with 22 species. Sarwade and Khillare ${ }^{[56]}$ reported 60 species from Ujani wetland where Cyprinidae was dominant with 36 species. Das and Sabitry ${ }^{[57]}$ reported 62 ornamental fish species from the river island, Masuli, Assam where as Cyprinidae was dominant with 10 species reported from Asan wetland, Dehradun by Ishaq and Khan ${ }^{[58]}$.Kumar et al. ${ }^{[19]}$ reported 6 species from Sandi wetland where as Bano and Seraiuddin [37] recorded 10 species from Bakhira Tal, Uttar Pradesh. Das ${ }^{[18]}$ studied the occurrence of 40 species of fishes belonging to 31 genera under six orders and 15 families from Rasik beel wetlands, West Bengal. Cyprinidae was the dominant family with 14 species followed by Channidae with four species, Ambassidae and Bagridae with three species each, Nandidae, Mastacembelidae, Belontidae, Siluridae and Clariidae with two species each whereas Cobitdae, Belonidae, Gobiidae, Anabantdae, Tetraodontdae and Notopteridae were represented by a single species each. The status of species of this beel included one endangered species, one Vulnerable species and four Near Threatened species. Recently, Prakash [53] and Prakash and Singh ${ }^{[38]}$ recorded 7 species each of Cyprinidae family from Semara Taal, A Wetland of District, Siddharthnagar and Baghel Taal, a Wetland of District Bahraich, Uttar Pradesh. The present study 20 species belonging 17 genera, 4 orders and 11 families from six wetlands were recorded. It may be more species can find from the all the wetlands. Thus, it is needed to explore more fish diversity from the different wetlands of Uttar Pradesh. It was also observed that all the six wetlands are in surrounding agricultural fields and heavy encroachment by villagers with their cattles spoil the wetlands ecosystem.

The diversity indices of all the six wetlands during present investigations shows inconsistency at species level all the study wetlands these variations may be due to variation in habitat and different conditions such as food availability, primary production of plants and algae, bottom type depth, marginal vegetation, predatory birds, reptiles and water pollution etc. Present findings, while there are no reports available to compare on population structures of fishes inhabiting different wetlands of Uttar Pradesh. But reports are available on different wetlands and rivers in the country, Bano and Seraiuddin ${ }^{[26]}$ studied on Simpson diversity index, fish species richness and abundance assessed for the fishes of three different sampling sites of river Gomti, at Lucknow Region were found to be statistically significant $(\mathrm{p}<0.05)$. Das (2018) recorded maximum fish diversity was recorded in the monsoon season $\left(\mathrm{H}^{\prime}=2.876\right)$ as compared with pre monsoon 
$\left(H^{\prime}=2.124\right)$ and post monsoon $\left(H^{\prime}=1.735\right)$. The evenness index varied from 0.640 (post monsoon) to 0.822 (monsoon), which indicates uneven distribution of fishes in Rasik beel wetland of West Bengal. Shukla Das et al. ${ }^{[48]}$ studied the Shannon Wiener Index ( $H^{\prime}$ ) was found to be maximum at R6 (3.254) followed by R7 (3.24) and R8 (3.074) sites, all constituting the lowland stretch of the Ramganga river, A mid-Himalayan tributary of river Ganga.

Sadly, many species are disappearing before, they have been identified. These wetlands rich in faunal species, but they are still hidden biodiversity in need of improved innovations. According United Nation Development Programme (UNDP) a changing climate also presents threats to the national populations of fishes. Increased periods of drought results in high pressure on key water wetlands, reservoirs, rivers, lakes, ponds, are causing water level to drops and wetlands hostiles degraded.According to Prasad et al. ${ }^{[59]}$ that India is facing tremendous anthropogenic pressure, threatening and leading to extinction of fish species because of degradation of environment which alter the food web structure at the primary and secondary production levels of the ecosystem. Vijayan et al. ${ }^{[60]}$ was also reported high concentrations of pesticides in fishes of the wetlands of Uttar Pradesh, which was higher than the maximum residue limits as suggested by Food and Drug Administration. Vass et al. ${ }^{[61]}$ assessed that the impact of climate change on inland fisheries in River Ganga and its plains in India.

Wetland environments are experiencing serious threat to both biodiversity and ecosystem stability. Working on conservation of biodiversity in freshwater ecosystems including wetlands, a number of workers such as Williams et al. [62], Warren and Burr ${ }^{[63]}$, Cowx ${ }^{[64]}$, as well as Suski and Cooke ${ }^{[65]}$ and several workers suggested many strategies such as mapping and modelling of wetlands for monitoring and preparation of inventory to solve the crisis. The wise use, surveys and intensive studies of different wetland ecosystems will bring out better results for the conservation of the wetlands. The preservation of wetland diversity is crucial not only for conservation of their rich biodiversity but also for meeting the basic needs of the local population.

\section{Conclusion}

The present study has documented the fish diversity of six wetlands and revealed that this wetland is endowed with rich diversity of fish species. Like many other wetlands too, is facing threat due to anthropogenic activities and indiscriminate fishing activity and pesticides use especially during the summer months. In order to ascertain the future of this wetlands, conservation and management plans need to be formulated and the baseline data generated on fish diversity would be helpful in formulation of effective conservation strategies for different wetlands of Uttar Pradesh.

\section{Acknowledgements}

The author is thankful to Director, Zoological Survey of India Kolkata for constant encouragement time to time for writing the manuscript and Officer-in-charge, Northern Regional Centre, Zoological Survey of India, Dehradun for the providing facilities.

\section{References}

1. Shinde SE, Paithane Bhandare R, Sonawane DL. Ichthyofaunal diversity of Harsool Savangi Dam district Aurangabad (M.S) India. World Journal Fresh Marine
Science 2009; 1 (3):141-143.

2. Chandra K, Gopi KC, Rao DV, Valarmathi K, Alfred JRB. Current Status of Freshwater Faunal Diversity in India (Published by the Director, Zoological Survey of India, Kolkata) 2017, 1-624.

3. Pathak AK, Sarkar UK, Dayal R, Singh SP. UPF Base-A freshwater fish diversity database of Uttar Pradesh, India. Indian Journal of Animal Science 2019;89(3):347-354.

4. Hamilton Buchanan. An Account of the Fishes Found in the River Gangas and its Branches. Printed for Archibaldconstable and company, Edinburgh and Hurst, Robinson and Co - 90, Cheapside London 1822;1(7)405.

5. Day F. The Fishes of India, Being A Natural History of the Fishes Known toInhabit the Seas and Fresh Waters of India, Burma and Ceylon. Ceylon textand atlas in 4 pts. London 1878;1(2):4.

6. Day F. The Fishes of India, Being A Natural History of the Fishes Known toInhabit the Seas and Fresh Waters of India, Burma, and Ceylon. Today and Tomorrow's Book Agency 1886;1(2):778.

7. Menon AGK. Check list- Freshwater fishes of India. Records of the Zoological Survey of India. Occasional Papers 1999;175:366.

8. Talwar PK, Jhingran AG. Inland fishes of India and adjacent countries. Oxford \& IBH Publishing Co., New Delhi, Bombay \& Calcutta 1991;1(2):1-1158.

9. Kottelat M, Whitten T. Freshwater biodiversity in Asia with special reference to fish. World Bank Technical Paper 1996;343:1-59.

10. Jayaram KC. The freshwater fishes of the Indian Region. Narendra Publishing House, Delhi 1999;6:551.

11. Johal MS. Ecology of Hill Streams of Himachal Pradesh and Garhwal Region with Special Reference to Fish Communities. Final Report US Fish and Wildlife Service Grant No INT/FWS-2002; 30.

12. Lakra WS, Singh AK, Ayyappan S. Fish Introductions in India: Status, Challenges and Potentials. Narendra Publishing House, New Delhi 2008.

13. Lakra WS, Pandey AK. Fish germplasm resources of India with special emphasis on conservation and rehabilitation of threatened species. In: Goswami, UC, Dilip Kumar eds, Aquaculture Management. Narendra Pub. House, Delhi 2009, 85-104.

14. Kapoor D, Dayal R, Ponniah AG. Fish biodiversity of India, National Bureau of Fish Genetic Resources Lucknow, India 2002, 775.

15. Lakra WS. Fish biodiversity of Uttar Pradesh: issues of livelihood security, threats and conservation. In: National Conference on Biodiversity, Development and Poverty Alleviation. Uttar Pradesh State Biodiversity Board, Lucknow 2010, 40-45.

16. Paunikar S, Tiple A, Jadhav SS, Talmale, SS. Studies on Ichthyofaunal diversity of Gour River, Jabalpur, Madhya Pradesh, Central India. World Journal Fish and Marine Science 2012;4(4):356-359.

17. Gopi KC, Mishra SS, Kosygin L. Pisces: 527-570. In, Current Status of Freshwater Faunal Diversity in India, (Eds. Chandra K, Gopi KC, Rao DV, Valarmathi K, Alfred J.R.B.) (Published by the Director, Zoological Survey of India,, Kolkata) 2017, 1-624.

18. Das RK. Fish diversity and the conservation status of a wetland of cooch Behar District, West Bengal, India. Journal of Threatened Taxa 2018;10(3):11423-11431.

19. Kumar U, Choudhary S, Kumar M, Paswan R. 
Physicochemical parameters of Gamhi water body of the Kaula Chaur (wetland) of Begusaraj District (Bihar). Proc. Zool. Soc. India 2015;14(1):1-6.

20. Bassi N, Dineshkumar M, Sharma A, Pardha-Saradhi P. Status of wetlands in India: A review of extent, ecosystem benefits, threats and management strategies. Journal of Hydrology 2014;2:1-19.

21. Sarkar UK, Pathak AK, Lakra WS. Conservation of freshwater fish resources of India: new approaches, assessment and challenges. Biodiversity Conservation 2008;17:2495-2511.

22. Pathak AK. Empirical Assessment of Fish Diversity of Uttar Pradesh, India: Current Status, Implcation and Strategies for Management. International Journal of Fisheries Science Research 2018;2(1):1005.

23. Srivastava GJ. Fishes of U.P. \& Bihar. 9 th Edn. Vishwavidyalaya Prakashan, Varanasi (India) 2002.

24. Sarkar UK, Gupta BK, Lakra WS. Biodiversity, ecohydrology, threat status and conservation priority of the freshwater fishes of river Gomti, a tributary of river Ganga (India). Environment 2010;30(1):3-17.

25. Gopi KC, Kosygian L. Pisces: Fauna of Uttar Pradesh. State Fauna Series, (Published by Director, Zoological Survey of India, Kolkata) 2015;22(1):7-30

26. Bano F, Seraiuddin M. Biodiversity, Threat Status and Conservation Priority of Icthyofauna of River Gomti at Lucknow Region, India Biodiversity Journal 2016;7(4):913-922.

27. Jha KK. Challenges in Sustainable Management of Wetland Based Sanctuaries of Uttar Pradesh with Reference to Avian diversity.-UP State Biodiversity Board, Lucknow, Uttar Pradesh 2015, 14-29.

28. Srivastava GJ. Fishes of UP and Bihar. 3rd ed. Vishwavidyalaya Prakashan, Varanasi 1988.

29. Mishra D, N, Moza U. Evaluation of fish and fishery resources in river Yamuna Part 1, Journal of Indian Fisheries Society, India 2001;33(1):93-99.

30. Kumar P, Rao AP. Current status of fish fauna of river Gomti in Faizabad and Sultanpur districts of U.P., India. Asian Journal of Animal Science 2009;3(2):225-230.

31. Sarkar UK, Pathak AK, Sinha RK, Sivakuma K, Pandian AK, Pandey A et al. Freshwater fish biodiversity in the River Ganga (India): changing pattern, threats and conservation perspectives. Reviews in Fish Biology \& Fisheries 2011. DOI 10.1007/s11160-011-9218-6.

32. Das BK. Assessment of fish and fisheries of the Ganga river system for developing suitable conservation and restoration plan. Mid Term Report submitted to National Mission for Clean Ganga (Ministry of Water Resources, River Development and Ganga Rejuvenation) 1st Floor, Major Dhyan Chand National Stadium, India Gate, New Delhi 2019.

33. Verma AK, Prakash S. Fish biodiversity of Alwara lake of District Kaushambi, Uttar Pradesh, India. Research Journal of Animal Vetenary and Fisheries Science 2016;4(4):5-9.

34. Verma AK.. Distribution and Conservation Status of Fishes reported from Muntjibpur Pond of Allahabad (U.P.). International Journal Scientific World 2017;5(1):50-53.

35. Verma AK. A Study of Fish Distribution in Balapur Pond of Prayagraj (U.P.). International Journal on Biological Science 2019;10(1):7-10.

36. Kumar A, Kanaujia A, Kushwaha S, Kumar A. A biodiversity hub: Sandi Bird Sacntuary, Hardoi, Uttar Pradesh. International Journal of Applied Biology and Pharmacology Technology 2015; 6 (2):273-288.

37. Bano F, Serajuddin M. Checklist of fishes of the Bakhira Tal and their conservation status. Indian Journal of Fisheries 2018;65(2):124-128. 10.21077/ijf.2018.65.2.70567-16.

38. Prakash S, Singh D. Conservation Status of Ichthyofauna of Baghel Taal, a Wetland of District Bahraich (U. P.), India. Iconic Research and Engineering Journal 2020;3(11):52-56.

39. Shannon CE, Wiener W. The mathematical theory of communication. University Illinois Press, Urbana, 1963, 36.

40. Simpson EH. Measurement of Diversity, Nature, Lond 1949, 163-188.

41. Margalef R. Perspective in ecological theory, University of Chicago 1958, 112.

42. Das SM, Nath S. The icthyofauna of Jammu province (J\&K). Kashmir Science 1966;2(1-2):65-78.

43. Marais JFK. Some factors that influence fish abundance in South African estuaries. South African Journal of Marine Science 1988;6:67-77.

44. Kar D, Nagarathna AV, Ramachandra TV, Day SC. Fish diversity and conservation aspects in an aquatic ecosystem in Northeastern India. Zoos Print Journal 2003;21(7):2308-2315.

45. Mishra A, Raut D, Patnaik L. Fisheries and hydrography of Baitarini at Jajpur, Odisha East coast of India. International Journal of Scientific and Research Publication 2013;3(6):2250-3153.

46. Gandotra R, Sharma P. Study of Ichthyofaunal Diversity in a stream in sunderbani district Rajouri, Jammu (J\&K). International Journal of Multidisciplinary Research and Development 2015;2(9):401-404.

47. Razak A, Mohamed M, Kadim, Younis KH, Hameed E. Status of fish Assamblage structure in the Garmat Ali River, Iraq 2017, 17(22).

48. Shukla Das SC, Khan AU, Absar A, Dubey VK, Joshi KP. Piscine diversity, Community strucuture and distribution patterns of the west Ramganga River: A midHimalayan tributary of river Ganga. Indian Journal of Animal Sciences 2020;90(1):20-26.

49. Husaain A. Pisces. Fauna of Asan Wetland, Published by Director, Zool. Surv. India Wetland Ecosystem Series 2003;5:23-26.

50. Das D, Sen A, Mitra P. Major Fauna of Rasik Beel wetland complex (WB). Zoological Survey of India, Occasional Paper 2013;343:1-76

51. Suvi S, Shibu S. Icthyofaunal diversity of a wetland ecosystem. Uttar Pradesh Journal of Zoology 2016;36(2):113-116.

52. Gautam P, Ananthani PS, Ramasubramanian V, Sharma A, Jha BC. Assessment of Fisheries and Management in Rihand Reservoir, Uttar Pradesh. Current Agricultural Research Journal 2018;6(3):378-389.

53. Prakash S. Fish diversity of Semara Taal, A Wetland of District Siddharthnagar (U. P.), India. International Journal of Fisheries and Aquatic Research 2020;5(2):0709.

54. Jaiswal DP, Ahirrao KD. Ichthyodiversity of the Rangavali Dam, Navapur, District Nandurbar, Maharashtra State. Journal of Research Biology 2012;3:241-245. 
55. Devi Prasad AG, Venkataramana GV, Thomas M. Fish diversity and its conservation in major wetlands of Mysore. Journal of Environmental Biology 2009;30:713718.

56. Sarwade JP, Khillare YK. Fish diversity of Ujani wetland, Maharashtra, India. The Bioscan 2010;1:173179.

57. Das MK, Sabitry B. Ichthyofaunal Resources of Inland water Bodies of the River Island Majuli, Assam, India. Asian Journal of Experimental Biological Sciences 2012;3(1):51-58.

58. Ishaq F, Khan A. Comparative assessment of icthyofauna of River Yamuna and River Asan and the impact of heavy metals on fish density and diversity. Bio Chemistry, An Indian Journal 2013;7(4):131-136.

59. Prasad SN, Ramachandra TV, Ahalya NT, Sengupta T, Kumar A, Tiwari AK. Conservation of wetlands of IndiaA review. Tropical Ecology 2002;43:173-186.

60. Vijayan VS, Prasad SN, Vijayan L, Muralidhararn S. Inland wetlands of India conservation priorities. Salim Ali Centre for Ornithology and Natural History, Coimbatore 2004, 532.

61. Vass KK, Das MK, Srivastava PK, Dey S. Assessing the impact of climate change on inland fisheries in River Ganga and its plains in India. Aquatic. Ecosystem and Health Management 2009;12(2):138-151.

62. Williams JE, Johnson JE, Hendricson DA, ContreerasBalderas S, Williums JD, Navarro-Mendoza M, McAllister DE, Deacon JE. Fishes of North America endangered, threatened or of special concern. Fisheries 1989;14:2-20.

63. Warren ML, Jr Burr BM. Status of freshwater fish of the United States: overview of an imperiled fauna. Fisheries 1994;19:6-18.

64. Cowx IG. Analysis of threats to freshwater fish conservation: past and present challenges. In: CollaresPereira MJ, Cowx IG, Coelho MM. (Eds.), Conservation of freshwater fishes: option for the future. Blackwell Scientific Press, UK 2002, 201-220.

65. Suski CD, Cooke SJ. Conservation of aquatic resources through the use of freshwater protected areas: opportunities and challenges. Biodiversity Conservation 2006;16:2015-2029. 